Original research article

\title{
14-3-3 $\zeta$ protein protects against brain ischemia/reperfusion injury and induces BDNF transcription after MCAO in rat
}

\author{
Naeemeh Khalesi ${ }^{1}$, Mojgan Bandehpour ${ }^{2}$, Mohammad Reza Bigdeli ${ }^{3,4}$, Hassan Niknejad ${ }^{5}$, \\ Ali Dabbagh ${ }^{6}$, Bahram Kazemi ${ }^{1,2}$ * \\ ${ }^{1}$ Shahid Beheshti University of Medical Sciences, School of Advanced Technologies in Medicine, Biotechnology Department, Tehran, Iran \\ 2 Shahid Beheshti University of Medical Sciences, Cellular and Molecular Biology Research Center, Tehran, Iran \\ ${ }^{3}$ Shahid Beheshti University, Faculty of Life Sciences and Biotechnology, Department of Animal Sciences and Biotechnology, Tehran, Iran \\ ${ }^{4}$ Shahid Beheshti University, Institute for Cognitive and Brain Science, Tehran, Iran \\ ${ }^{5}$ Shahid Beheshti University of Medical Sciences, School of Medicine, Department of Pharmacology, Tehran, Iran \\ ${ }^{6}$ Shahid Beheshti University of Medical Sciences, Anesthesiology Research Center, Tehran, Iran
}

\begin{abstract}
Brain ischemia is a leading cause of death and disability worldwide that occurs when blood supply of the brain is disrupted. Brainderived neurotrophic factor (BDNF) is a protective factor in neurodegenerative conditions. Nevertheless, there are some problems when

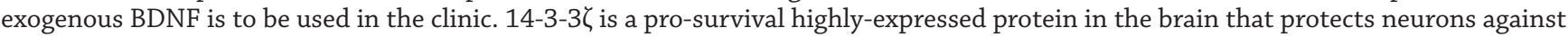
death. This study evaluates 14-3-3 effects on BDNF transcription at early time point after ischemia and its possible protective effects against ischemia damage. Human 14-3-3 protein was purified after expression. Rats were assigned into four groups, including sham, ischemia, and two treatment groups. Stereotaxic cannula implantation was carried out in the right cerebral ventricle. After one week,

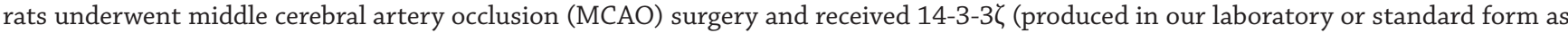
control) in the middle of ischemia time. At $6 \mathrm{~h}$ of reperfusion after ischemia, brain parts containing the hippocampus, the cortex, the piriform cortex-amygdala and the striatum were collected for real time PCR analysis. At $24 \mathrm{~h}$ of reperfusion after ischemia, neurological function evaluation and infarction volume measurement were performed. The present study showed that $14-3-3 \zeta$ could up-regulate BDNF mRNA at early time point after ischemia in the hippocampus, in the cortex and in the piriform cortex-amygdala and could also improve neurological outcome and reduce infarct volume. It seems that $14-3-3 \zeta$ could be a candidate factor for increasing endogenous $\mathrm{BDNF}$ in the brain and a potential therapeutic factor against brain ischemia.
\end{abstract}

Keywords: 14-3-3ఢ; BDNF; Brain ischemia; MCAO; Purification

\section{Highlights:}

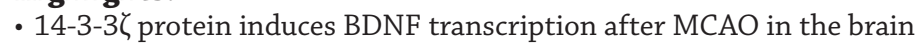

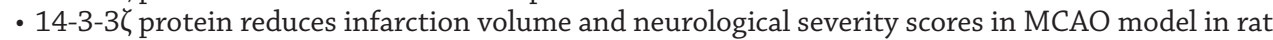

-14-3-3 $\zeta$ protein is a candidate factor for increasing endogenous BDNF in the brain an a potential therapeutic factor against ischemic neurodegeneration

\section{Introduction}

Ischemic brain injury with high mortality and disability in survivors, takes place in stroke, and is also a common cause of death and neurologic dysfunctions after cardiac arrest (Benjamin et al., 2018; Chalkias and Xanthos, 2012; Hankey, 2017; Nolan et al., 2008; Sacco et al., 2013). Although tissue plasminogen activator, endovascular thrombectomy, and hypothermia have been successfully used clinically, many researches have been conducted and are also underway to introduce a protective method against cerebral ischemia (Chalkias and Xanthos, 2012; Hankey, 2017).
14-3-3 proteins are conserved regulatory proteins with average molecular weight of $30 \mathrm{kD}$ found in all eukaryotes. There are seven known 14-3-3 isotypes in mammalian $(\beta, \gamma, \varepsilon, \eta, \zeta$, $\sigma, \tau / \theta)$ and their highest tissue expression is in the brain. They interact with various targets in the brain and play role in vital processes via scaffolding, chaperoning and regulating their target's localization (Berg et al., 2003; Cau et al., 2018; Ferl et al., 2002). 14-3-3 proteins are up-regulated in ischemic astrocytes and in human and rat brains with infarction (Chen et al., 2005; Kawamoto et al., 2006; Pirim, 1998; Umahara et al., 2007). 14-3-3 $\zeta$ is encoded by YWHAZ gene and is known as a major pro-survival protein (Kasinski et al., 2014). Cerebrospi-

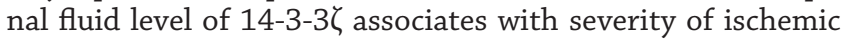

\footnotetext{
* Author for correspondence: Bahram Kazemi, Shahid Beheshti University of Medical Sciences, School of Advanced Technologies in Medicine, Biotechnology Department, 19839-63113, Tehran, Iran; e-mail: kazemi@sbmu.ac.ir http://doi.org/10.32725/jab.2019.007

Submitted: 2018-09-24 • Accepted: 2019-04-04 • Prepublished online: 2019-04-15

J Appl Biomed 17/2: 99-106 • EISSN 1214-0287 • ISSN 1214-021X

(c) 2019 The Authors. Published by University of South Bohemia in České Budějovice, Faculty of Health and Social Sciences.

This is an open access article under the CC BY-NC-ND license.
} 
damage in rat and is introduced as a surrogate biomarker for acute brain injury (Siman et al., 2005). Depletion of zeta isoform evokes cell death in mouse hippocampal culture (Murphy et al., 2008). Up regulation of zeta isoform is protective in vitro and in vivo under conditions having common patho-mechanism, to ischemia (Brennan et al., 2013; 2015). It has been reported that, $14-3-3 \zeta$ regulates brain-derived neurotrophic factor (BDNF) transcription in neuronal cells (Neasta et al., 2011).

BDNF is a nerve growth factor produced in different regions in the brain with the highest levels in the hippocampus and cerebral cortex and is essential for neuronal function and survival throughout life (Nagahara and Tuszynski, 2011; Zuccato and Cattaneo, 2009). BDNF is considered as a key target for drug development in neurodegenerative diseases (The BDNF StudyGroup, 1999; Hernandez-Chan et al., 2015; Levivier et al., 1995; Lu et al., 2013; Nagahara et al., 2009; Shruthi et al., 2017; Silva et al., 2015). Intraventricular delivery (Beck et al., 1994; Schäbitz et al., 1997) and intravenous bolus (Müller et al., 2008; Schäbitz et al., 2000, 2007) of BDNF, has been shown to be protective in cerebral ischemia in rat, whereas blockade of endogenous BDNF activity was reported to intensify cerebral ischemia (Larsson et al., 1999). Since effective delivery of BDNF to the brain is a challenge, strategies to induce endogenous production of BDNF in the brain are helpful for its clinical development.

We hypothesized that: (A) 14-3-3 $\zeta$ may increase BDNF mRNA after cerebral ischemia; (B) 14-3-3 treatment may protect against cerebral ischemic damage. Intracerebroventricular (i.c.v.) delivery of $14-3-3 \zeta$ was performed during middle cerebral artery occlusion (MCAO) in rat and the effects on BDNF mRNA expression and neurological behavior and infarct volume after ischemia were assessed.

\section{Materials and methods}

\section{Ethics statement}

All animal experiments were reviewed and approved by our university animal care committee (IR.SBMU.RETECH. REC.1395.263). All experiments were performed in accordance with relevant guidelines and regulations.

\section{Synthesis and sub cloning of human 14-3-3 $\zeta$ gene}

The coding sequence of the human $14-3-3 \zeta$ gene (Accession Number: NM-003406) was selected and optimized into the most preferred codons of the E. coli codon usage system without any changes in amino acid sequence. The resulting sequence was synthesized into the pGEM-B1 vector

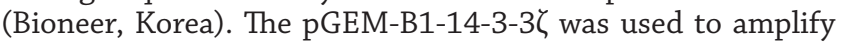
14-3-3 $\zeta$ coding sequence by PCR using following set of primers: forward, 5'-ATTCGGATCCTATGGACAAAAACGAACTGGT-3'; reverse, 5'-TACAGTCGACGTTTTCACCACCTTCACCCAGC-3'. Amplified sequence was then ligated into the BamHI and SalI restriction enzyme sites of the prokaryotic expression vector $\mathrm{pET} 26 \mathrm{~b}$ and the process was confirmed by DNA sequencing.

\section{Expression and purification of 14-3-3 protein}

E. coli Bl21 (DE3) was transformed with pET26b-14-3-3 construct. A single clone was selected and grown at $37{ }^{\circ} \mathrm{C}$ at $200 \mathrm{rpm}$ in $2 \mathrm{ml} \mathrm{LB}$ medium containing $30 \mu \mathrm{g} / \mathrm{ml}$ kanamycin to $\mathrm{OD} 600=1$. Every $2 \mathrm{ml}$ culture was diluted into $50 \mathrm{ml}$ of fresh LB media containing $30 \mu \mathrm{g} / \mathrm{ml}$ kanamycin and cultured at $37^{\circ} \mathrm{C}$ at $200 \mathrm{rpm}$ to $\mathrm{OD} 600=0.6$. The $14-3-3 \zeta$ His- tagged protein was induced using $1 \mathrm{mM}$ isopropyl- $\beta$-D-thiogalacto- side (IPTG). Bacterial cells were pelleted by centrifugation at $10,000 \times \mathrm{g}$, after $5 \mathrm{~h}$ growing at $37^{\circ} \mathrm{C}$ at $200 \mathrm{rpm}$. The pellet was suspended in binding buffer $\left(20 \mathrm{mM} \mathrm{NaH}_{2} \mathrm{PO}_{4}, 500 \mathrm{mM}\right.$ $\mathrm{NaCl}, \mathrm{pH} 8$ ) and cells were lysed by sonication on ice. The lysate was centrifuged at $15.000 \times \mathrm{g}$ for $15 \mathrm{~min}$ at $4{ }^{\circ} \mathrm{C}$. The supernatant was loaded onto a $\mathrm{Ni}^{2+}$-NTA resin column (Invitrogen) pre-equilibrated with binding buffer. The column was washed by washing buffer $\left(20 \mathrm{mM} \mathrm{NaH}{ }_{2} \mathrm{PO}_{4}, 500 \mathrm{mM} \mathrm{NaCl}, 40 \mathrm{mM}\right.$ imidazole, $\mathrm{pH}$ 8). Stepwise imidazole gradient of elution buffer (20 mM NaH $\mathrm{PO}_{4}, 500 \mathrm{mM} \mathrm{NaCl}, 50$ to $500 \mathrm{mM}$ imidazole, $\mathrm{pH}$ 8) was used for protein elution. A $15 \mathrm{kDa}$ molecular weight cutoff dialysis tubing (D0530 Sigma, Germany) was used and eluted fractions were dialyzed against PBS, pH 7.4 at $4{ }^{\circ} \mathrm{C}$. The recombinant protein was confirmed by Western blot, using anti-6X-His-tag antibody (1:1000, Abcam, UK). The purified protein was named $\mathrm{KBK \zeta}$.

\section{Animal study design}

A total of 39 adult male Wistar rats (250-300 g, aged 5 to 7 weeks, Pasteur Institute, Karaj, Iran) were housed under standard $12 \mathrm{~h}$ light/dark cycle and with ad libitum access to food and water at $25{ }^{\circ} \mathrm{C}$. Animals were studied in two groups: 18 for real time PCR analysis (3 intact rats, 3 sham-operated animals received vehicle, 4 ischemic rats received vehicle, 4 ischemic rats treated with 14-3-3 $\zeta$ made in our laboratory, and 4 ischemic rats treated with $14-3-3 \zeta$ provided from Creative BioMart, USA, as standard control); 21 for neurological severity score and infarction size assessments (3 sham-operated animals, 6 ischemic animals, 6 ischemic animals treated with our laboratory $14-3-3 \zeta$ and 6 ischemic rats treated with standard 14-3-3ל). Ischemic animals underwent MCAO surgery. Rats in sham group were subjected to the same surgical procedures except the filament insertion.

\section{Cannula implantation}

Animals were anaesthetized by i.p. injection of the mixture of $100 \mathrm{mg} / \mathrm{kg}$ of ketamine and $10 \mathrm{mg} / \mathrm{kg}$ of xylazine. A 22 gauge guide cannula was implanted into the right lateral ventricle using a sterotax instrument [from the bregma: $-0.9 \mathrm{~mm}$ anteroposterior (AP), $\pm 1.5 \mathrm{~mm}$ Mediolateral (ML), $-3.0 \mathrm{~mm}$ dorsoventral (DV)]. The implanted cannula was fixed to anchored screws on the skull by dental cement and fitted with a mandarin. The procedure was verified by $2 \mu$ injection of methylene blue solution into the lateral ventricle of one rat. Cannulated rats were allowed to recover for one week before MCAO.

\section{Middle cerebral artery occlusion}

One week after cannulation, rats were anesthetized with chloral hydrate $(400 \mathrm{mg} / \mathrm{kg}$, i.p.) and transient occlusion of the middle cerebral artery was performed using the suture occlusion technique described by Longa et al. (1989). The right common carotid artery (CCA), the right external carotid artery (ECA) and the right internal carotid artery (ICA) were exposed briefly. The CCA and ECA were ligated. A 3-0 mono filament nylon suture, coated with silicon was introduced through an arteriectomy in the CCA, gently advanced into the ICA lumen 20 to $22 \mathrm{~mm}$, until resistance was felt. At this point, suture has blocked the origin of MCA and all sources of blood flow were occluded. The body temperature was maintained at $37{ }^{\circ} \mathrm{C}$ throughout the operation. After $1 \mathrm{~h}$ of $\mathrm{MCAO}$, reperfusion was performed by withdrawal of the filament.

\section{Intraventricular microinjection}

In the middle of MCAO (30 min of ischemia), rats were inject-

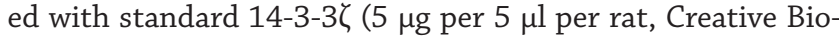




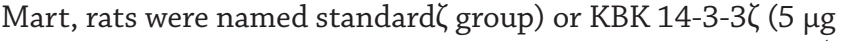
per $5 \mu \mathrm{l}$ per rat, made in our laboratory, rats were named $\mathrm{KBK} \zeta$ group), into the right lateral brain ventricle via an injection cannula tubed to a Hamilton micro syringes. Protein volumes of $5 \mu \mathrm{l}$ were infused over $3 \mathrm{~min}$. The injection cannula was left in the brain for at least $1 \mathrm{~min}$ after the injection, before being pulled so that backflow of the injected proteins is prevented. In real time PCR group, Ischemic control rats and sham-operated rats received vehicle in the same way as $14-3-3 \zeta$ treated groups. Since the standard form of the protein was purchased as a solution in $\mathrm{PBS}, \mathrm{KBK} \zeta$ was also prepared in $\mathrm{PBS}$, and this solvent was used as vehicle in control groups.

\section{Real time quantitative PCR}

Rats were sacrificed under deep anesthesia with chloral hydrate $(800 \mathrm{mg} / \mathrm{kg}$, i.p.) at $6 \mathrm{~h}$ of reperfusion after $1 \mathrm{~h} \mathrm{MCAO}$ or sham operation. Four parts from the brain right hemispheres including the hippocampus, the cortex, the piriform cortex-amygdala (Pir-Amygdala), and the striatum were separated and saved in $-80^{\circ} \mathrm{C}$ immediately until further processing.

Total RNA was isolated using RNeasy Mini Kit (QIAGENE, USA) following the manufacturer's instructions. RNA quality and concentration were determined using agarose gel electrophoresis and a Multi-Mode Reader (SYNERGY HTX, Bio Tek). Every RNA sample $(1 \mu \mathrm{g})$ was reverse transcripted to cDNA using the RevertAid First Strand cDNA Synthesis Kit (FERMENTASE, USA), following the manufacturer's recommendations. Volumes corresponding to $1 / 20$ of the resulting cDNA were subjected to qPCR by using the following set of primers: BDNF (forward, 5'-GGC TGA CAC TTT TGA GCA CGT-3'; reverse, 5'CTC CAA AAG GCA CTT GAC TGC TC-3'), GAPDH (forward, 5'-AGT TCA ACG GCA CAG TCA AG-3'; reverse, 5'-TAC TCA GCA CCA GCA TCA CC-3') and AccuPower $2 \times$ GreenStar qPCR Master (BIONEER, Korea). PCR reactions were run in duplicates on the real-time PCR system (Step One Plus, Applied Biosystems). The conditions were: holding stage at $95{ }^{\circ} \mathrm{C}$ for 10 min followed by 40 cycles of $95^{\circ} \mathrm{C}$ for $15 \mathrm{~s}$ and $60{ }^{\circ} \mathrm{C}$ for $1 \mathrm{~min}$ followed by melt curve stage at $95^{\circ} \mathrm{C}$ for $15 \mathrm{~s}$ and $60{ }^{\circ} \mathrm{C}$ for $1 \mathrm{~min}$ and $95^{\circ} \mathrm{C}$ for $15 \mathrm{~s}$. Gene expression was assessed using the $\Delta \Delta C$ t method (Livak and Schmittgen, 2001). Results were normalized to GAPDH expression and expressed as log base 2 of the relative gene expression vs. ischemia as calibrator (Yuan et al., 2006).

\section{Neurological function evaluation}

At $24 \mathrm{~h}$ of reperfusion after $1 \mathrm{~h} \mathrm{MCAO}$, rats were subjected to neurological function evaluation (Long et al., 2013). Scoring system includes five parts and a maximum score of 18 $(0=$ normal, $1-6=$ minor injury, $7-12=$ moderate injury, 13-18 = sever injury, 18 = complete loss of neurological function). Rats with scores $>6$, were considered successful ischemic.

\section{Infarct volume assessment}

After scoring neurological function, rats were sacrificed under deep anesthesia with chloral hydrate (800 mg/kg, i.p.) and the brains were separated and immersed in saline at $4{ }^{\circ} \mathrm{C}$ for $10 \mathrm{~min}$. Thereafter, six 2 -mm coronal sections were made from the frontal to temporal side and were stained with $2 \%$ 2,3,5-triphenyltetrazoliumchloride (TTC) at $37{ }^{\circ} \mathrm{C}$ for $30 \mathrm{~min}$ (Lin et al., 2013). The areas of the infarction (pale color) were measured using image J software (NIH image). Corrected infarct volume $=$ Left hemisphere volume - (Right hemisphere volume - Infarct volume).

\section{Statistical analysis}

Data were analysed by GraphPad Prism 7 software, using oneway ANOVA. Dunnett was used as the post test for multiple comparisons and statistical significance was measured as $P<0.05$.

\section{Results}

\section{Generation of pure 14-3-3 protein}

The recombinant protein, fused to $6 \mathrm{His}$-tag in its C-terminal was expressed inside bacterial cells, and showed a molecular mass of approximately $30 \mathrm{kDa}$ (Fig. 1).

\section{Assessment of BDNF mRNA expression}

Fig. 2 shows the BDNF mRNA expression data as log base 2 of relative BDNF mRNA expression (ratio) vs. ischemia group as calibrator. The results revealed that BDNF mRNA was increased significantly in ischemic vs. sham operated rats in the hippocampus, in the cortex and also in the pir-amygdala (log 2 expression ratio \pm SD of Ischemia vs. Sham: $1.03 \pm 0.37, P<$ $0.05 ; 0.87 \pm 0.08, P<0.05 ; 0.73 \pm 0.24, P<0.05$, respectively).

A

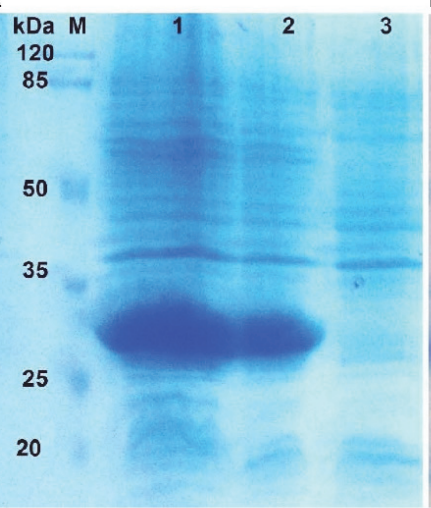

B

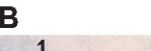

C

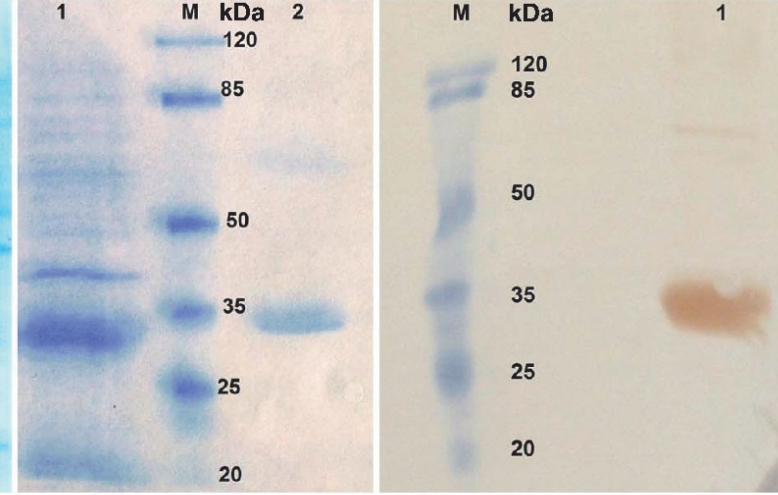

Fig. 1. Generation of $14-3-3 \zeta$ protein.

(A) Expression of 14-3-3 protein in E. coli BL21 (DE3) cells was induced by $1 \mathrm{mM}$ IPTG at $37^{\circ} \mathrm{C}$ and supernatant of bacterial cell lysate was loaded on SDS/PAGE gel and stained with Coomassie brilliant blue R250 after electrophoresis. Lane M, protein size marker; Lane 1, $5 \mathrm{~h}$ after induction; Lane 2, $3 \mathrm{~h}$ after induction; Lane 3, before induction. (B) Purification of recombinant His-tagged protein. Lane 1, supernatant of cell lysate;

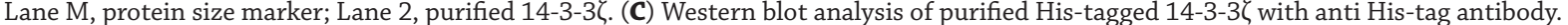

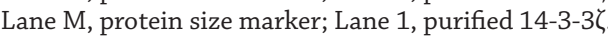



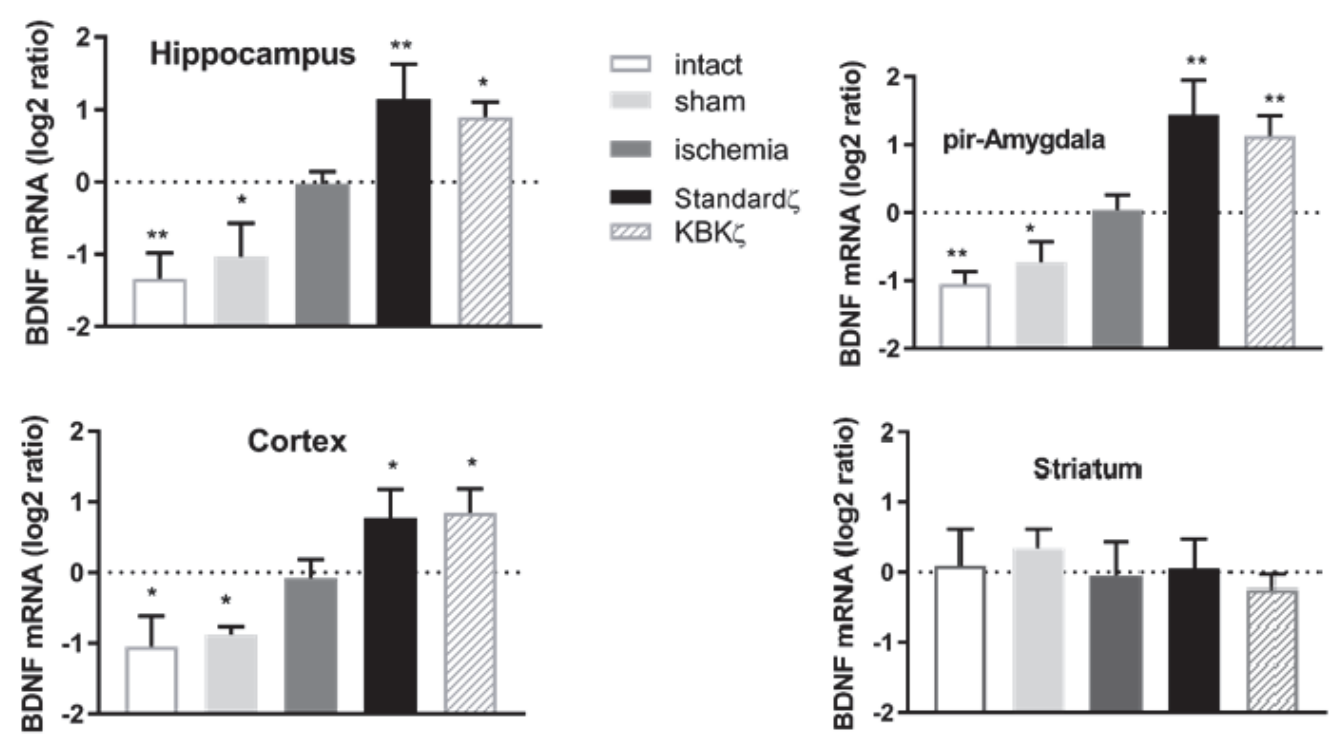

Fig. 2. $\mathrm{qPCR}$ analysis.

BDNF mRNA expression in four parts of brain, separated from five groups of animals [Intact $(n=3)$, sham ( $6 \mathrm{~h}$ after sham operation + PBS, $n=3)$, Ischemia (6 h reperfusion after $1 \mathrm{~h} \mathrm{MCAO}+\mathrm{PBS}, n=4)$, standard $\zeta(6 \mathrm{~h}$ reperfusion after $1 \mathrm{~h} \mathrm{MCAO}+$ standard $14.3 .3 \zeta, n=4)$ and $\mathrm{KBK \zeta}(6 \mathrm{~h}$ reperfusion

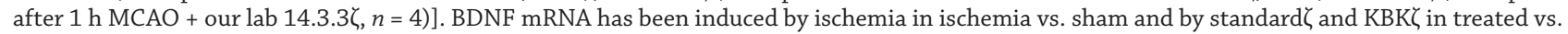
ischemia groups. Results are expressed as log base 2 ratio vs. ischemia as calibrator and are the average \pm SD of independent nonpooled samples assayed in duplicate.

* $P<0.05$ by One-Way ANOVA and Dunnet post-test for comparing every group to ischemia group as control.

** $P<0.01$.

The results also revealed that BDNF mRNA was up-regulated further by standard $14-3-3 \zeta$ in the hippocampus, in the cortex and also in the pir-amygdala (log 2 expression ratio $\pm \mathrm{SD}$ of Standard $\zeta$ vs. Ischemia: $1.14 \pm 0.39, P<0.01$; $0.78 \pm 0.32, P<0.05 ; 1.44 \pm 0.41, P<0.01$, respectively). KBK 14-3-3 also up-regulated BDNF mRNA in the hippocampus, in the pir-amygdala and in the cortex (log 2 expression ratio $\pm \mathrm{SD}$ of KBK $\zeta$ vs. Ischemia: $0.90 \pm 0.16, P<0.05 ; 0.84 \pm 0.27$, $P<0.05 ; 1.30 \pm 0.23, P<0.01$, respectively).

Thus, ischemia up-regulated BDNF mRNA by 2.042 -fold (log base 2 ratio $=1.03$ ) in the hippocampus and also standard

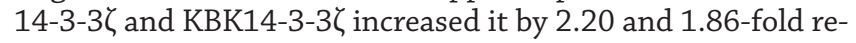
spectively. A 1.82-fold up-regulation of BDNF mRNA was ob-

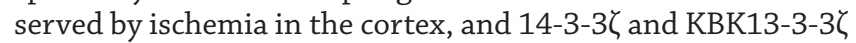
caused its further induction by 1.71 and 1.79-fold respectively. In the pir-amygdala, ischemia caused over expression of BDNF

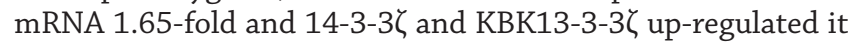
by 2.71 and 2.46 -fold respectively.

No significant elevation of BDNF mRNA was observed by ischemia in ischemic compared to sham operated animals

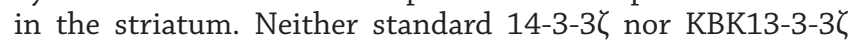
up-regulated BDNF mRNA in treated compared to untreated rats, in this part of brain (Fig. 2).

\section{Protection of 14-3-3 (against focal cerebral ischemia}

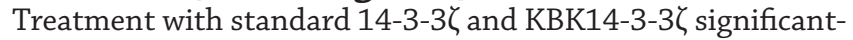
ly improved neurological function. Neurological severity score mean was 10 (8 to 11 ) in standard $\zeta$ group and 11 (8 to 12) in $\mathrm{KBK} \zeta$ group, while it was 14 (13 to 15 ) in ischemia group (Table 1).

Neurological severity score reduction was confirmed by infarct volume data. Recombinant 14-3-3 $\zeta$ (standard and KBK) significantly reduced total infarct size in the right hemisphere (Fig. 3).
Table 1. Neurological severity scores. Standard and KBK 14-3-3 reduced neurological severity scores.

\begin{tabular}{|c|c|c|c|c|c|c|}
\hline \multirow[t]{2}{*}{ Animal group } & \multicolumn{3}{|c|}{ Rats/Score scale } & \multirow[t]{2}{*}{ Total } & \multirow[t]{2}{*}{ Mean } & \multirow[t]{2}{*}{$P$ value } \\
\hline & $1-6$ & $6-12$ & $12-18$ & & & \\
\hline Ischemia & 0 & 0 & 6 & 6 & 14 & \\
\hline Sham & 3 & 0 & 0 & 3 & 3 & $*$ \\
\hline Standard $\zeta$ & 0 & 6 & 0 & 6 & 10 & $*$ \\
\hline 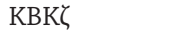 & 0 & 5 & 1 & 6 & 11 & * \\
\hline
\end{tabular}

* Significant difference compared to ischemia group by One-Way ANOVA and Dunnet post-test for comparing every group to ischemia group as control.

\section{Discussion}

In our knowledge it is the first time that the positive effect of 14-3-3 recombinant protein on BDNF transcription in the ischemic brain and also its protective effect in this pathogenic condition is reported. We purified $14-3-3 \zeta$ for conducting the experiments and the standard form of the protein was used as control to verify the prepared protein.

The findings of the present study showed that: 1 . BDNF mRNA was increased in the hippocampus, in the cortex and in the piriform cortex-amygdala, ipsilaterally, by $1 \mathrm{~h}$ focal cerebral ischemia after $6 \mathrm{~h}$ of reperfusion. 2. 14-3-3 $\zeta$ treatment up-regulated already increased BDNF mRNA in the hippocampus, in the cortex and in the piriform cortex-amygdala, ipsilaterally, at $6 \mathrm{~h}$ of reperfusion after MCAO in treated animals compared to untreated animals. 3. i.c.v. administration of 14-3-3 $\zeta$ improved neurological function and reduced cerebral infarct volume in this rat focal cerebral ischemia-reperfu- 
A
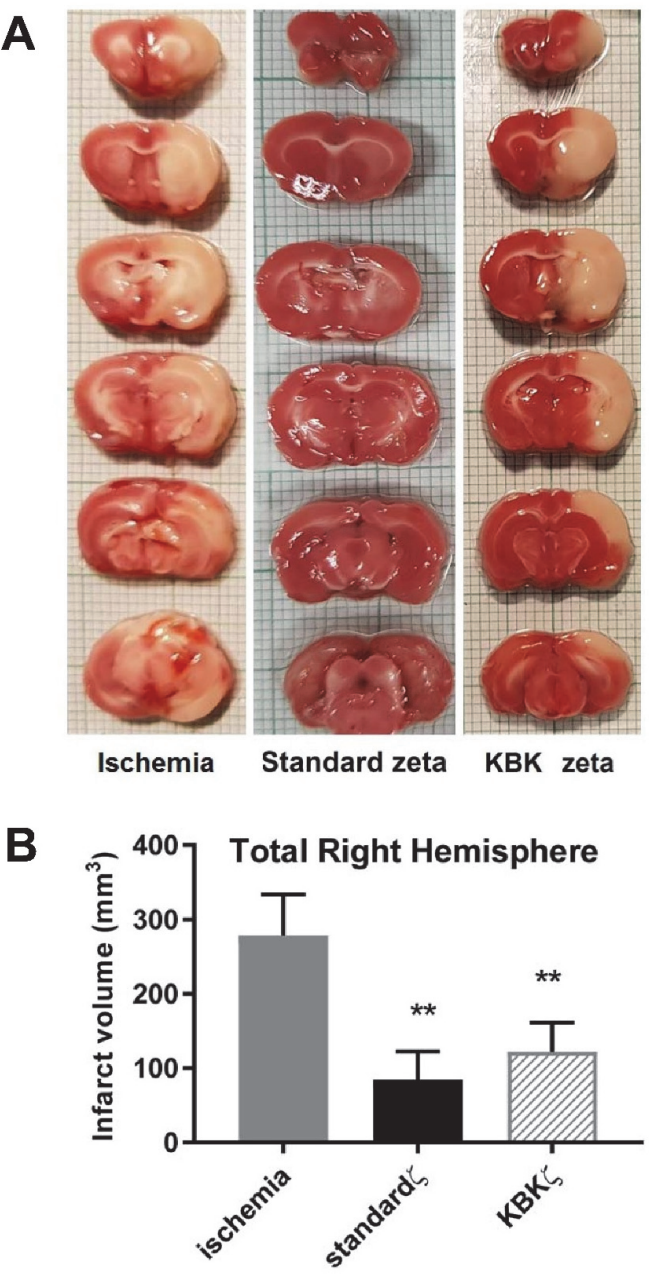

Fig. 3. Infarct volume analysis.

(A) Representative TTC-stained brain coronal sections from three groups of rats [Ischemia ( $24 \mathrm{~h}$ reperfusion after $1 \mathrm{~h} \mathrm{MCA0,} n=6$ ), standard $\zeta(24 \mathrm{~h}$ reperfusion after $1 \mathrm{~h} \mathrm{MCAO}+$ standard $14.3 .3 \zeta, n=6)$

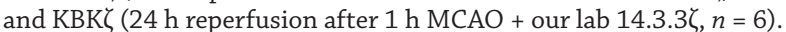

(B) Assessment of total right brain hemisphere infarct volume from each

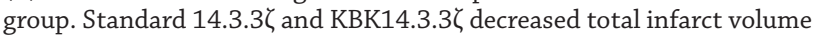
in right hemisphere. Results are the average $\pm S D$.

${ }^{*} P<0.05$ by One-Way ANOVA and Dunnet post-test for comparing every group to ischemia group as control.

${ }^{* *} P<0.01$.

sion model. The same results were concluded using standard

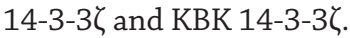

Induction of BDNF mRNA ipsilaterally, in the cortex, hippocampus and piriform cortex-amygdala, but not in the striatum, at $6 \mathrm{~h}$ reperfusion after ischemia, was observed in the present study and it confirmed other reports (Arai et al., 1996; Dmitrieva et al., 2016; Kokaia et al., 1995; Lindvall et al., 1992; Mengozzi et al., 2012; Rickhag et al., 2007; Schmidt-Kastner et al., 2001). BDNF is an immediate early gene whose transcription could take place in the absence of de novo protein synthesis and various stimuli can induce rapid and transient synthesis of its mRNA (Okuno, 2011). In situ hybridization data have shown that BDNF mRNA has been induced in the cerebral cortex ipsilaterally surrounding the ischemic core and bilaterally in the hippocampus at early time points after MCAO and then gradually decreased to the basal level by $24 \mathrm{~h}$. Based on their reports, no BDNF mRNA induction has been observed in the striatum (Arai et al., 1996; Kokaia et al., 1995). BDNF mRNA is absent in the striatum and BDNF protein is synthesized and anterogradely transported to the adult striatum from the cell bodies located in cerebral cortex, substantia nigra, amygdala, and thalamus (Baydyuk and Xu, 2014). Striatum is also a part of ischemic core in the MCAO model.

14-3-3 $\zeta$ could up-regulate the already increased level of BDNF mRNA in the hippocampus, cortex and piri-amygdala at early time point after ischemia. Brain ischemia disrupts neuronal $\mathrm{Ca}^{2+}$ homeostasis and cytoplasmic $\mathrm{Ca}^{2+}$ is increased dramatically and causes neuronal death after ischemia (Neumar, 2000). Elevation of intracellular calcium leads to the activation of cAMP/PKA, Ras/ERK, and CaM kinase pathways (Zheng et al., 2012). Direct interaction between 14-3-3 $\zeta$ and RACK1 has been reported to regulate BDNF transcription. It has been shown that this interaction is necessary for BDNF regulation in response to cAMP/PKA signaling and mediates translocation of RACK1 from cytosol to the nucleus and depletion of

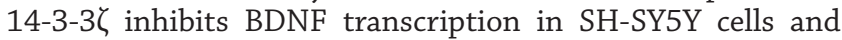
in hippocampal neurons in response to cAMP (Neasta et al., 2011). 14-3-3 ל has been shown to directly bind to Raf and activate MEK/ERK, finally leading to phosphorylation and activation of CREB (Freed et al., 1994). Finally, from this interaction, another group reported that 14-3-3 over expression activates the MEK/ERK pathway and consequently increases the binding of CREB to CRE, thus leading to transcriptional up-regulation of genes under regulation of $\mathrm{CRE}$ containing promoter in their system. By targeting MEK/ERK/CREB pathway, they observed the inhibition of gene of their interest (Chang et al., 2016). CREB is located in transcription regulatory system of BDNF gene (Chang et al., 2016; Zuccato and Cattaneo, 2009). CREB is a key transcription factor that modulates stimulus-dependent transcription. Activity-dependent BDNF expression is regulated by intracellular $\mathrm{Ca}^{2+}$ and CREB (Numakawa et al., 2010). Therefore, the finding of the present study that $14-3-3 \zeta$ administration was associated with elevation of BDNF mRNA in ischemia is line with regulatory effects of $14-3-3 \zeta$ reported by other groups.

BDNF exerts its protective effect through pro-survival mechanisms, regulating synaptic plasticity and neurogenesis (Nagahara and Tuszynski, 2011; Zuccato and Cattaneo, 2009). Recently, an excellent study has reported its protective effect on the cortex and hippocampus using single $\Psi \varepsilon R A C K$ treatment in an ischemic preconditioning model by which BDNF expression is up regulated (Neumann et al., 2015). Up regulation of BDNF mRNA in the brain after ischemia is an inherent mechanism; its pattern has been stated to be associated with its protectivity (Arai et al., 1996; Kokaia et al., 1995). It is also a mechanism, ischemic preconditioning takes advantage from. Based on the finding of the present study, 14-3-3 $\zeta$ has a positive effect on this inherent protective mechanism. Thus, it can be expected that 14-3-3 $\zeta$ may ameliorate ischemia damages by increasing BDNF expression.

14-3-3 $\zeta$ could reduce infarct size and reduce neurological severity score in this model of focal ischemia. In addition to the effects that $14-3-3 \zeta$ may have on BDNF production, it may exert its protective effect through other mechanisms, too. 14-3-3 as a major pro-survival protein (Kasinski et al., 2014), sequesters pro-apoptotic proteins like apoptosis signal-regulate kinase 1 (Ask 1) and Fkhrl1 (a member of Forkhead transcription factors) and antagonize their death-promoting activities (Berg et al., 2003). Knockdown of 14-3-3 ל causes endoplasmic reticulum stress and cell death in mouse hippocampal cultures. ER stress takes places as a consequence of disruption of cellular $\mathrm{Ca}^{2+}$ homeostasis. Transgenic overexpression of $14-3-3 \zeta$ is protective against ER stress in vivo (Brennan et al., 2013). ER stress involved genes are reported as part of dif- 
ferentially expressed genes after MCAO (Wang et al., 2017). Brennan et al. also reported protection of zeta protein overexpression against excitotoxicity-induced nerodegeneration in vivo (Brennan et al., 2013). Smani et al. (2018) have recently reported downregulation of 14-3-3 isoforms by kainic acid in vivo and proposed sustaining enough level of this proteins as a target of therapeutic intervention against neurodegeneration for neuronal injury induced by excitotoxicity. 14-3-3 proteins have shown neuroprotective effects by regulating apoptosis via targeting pro-apoptotic proteins (Fan et al., 2012; Masters et al., 2001; Noh et al., 2006; Zhu et al., 2014). Since 14-3-3 ( interacts with a variety of molecules, different mechanism could be proposed to explain its neuroprotectivity in our study.

Since BDNF has short half-life in plasma $(\sim 1 \mathrm{~h})$ and also poorly penetrates blood-brain barrier, its clinical potential as treatment against ischemia has been limited. The results of the present study introduce administration of $14-3-3 \zeta$ as an alternative method for increasing endogenous BDNF in the brain.

Despite BDNF that is a positively charged protein, 14-3-3 $\zeta$ is an acidic protein. Clearance of anionic molecules through glomerular infiltration is much smaller than that of the neutral and cationic molecules (Rennke et al., 1978). On the other hand, it has been reported that $14-3-3 \zeta$ could not cross the blood brain barrier (BBB) even in ischemia condition when the barrier is damaged (Zhu et al., 2014). These authors used this isoform intravenously $2 \mathrm{~h}$ before ischemia. In our study, 14-3-3 $\zeta$ was administered intraventriculary and its ability to cross the BBB remained unknown. Furthermore, BDNF protein level at later time points after ischemia was not assessed. Then, more studies are needed to reveal whether 14-3-3 $\zeta$ could pass intact BBB or enter the brain in ischemic condition when is used intravenously as well as if up-regulation of BDNF mRNA would lead to its protein level elevation at later time points.

Kawamoto et al proposed the possible involvement of 14-3-3 proteins in astrogliosis and intermediate filament (IF) formation (Kawamoto et al., 2006). Asterogliosis is a defensive astroglical reaction against ischemia and animals lacking IF in their reactive astrocytes have shown larger infarction after ischemia (Li et al., 2008) but nevertheless, it may have some negative effects on regeneration (Pekny and Pekna, 2014). Transgenic mice over expressing 14-3-3 $\zeta$ have shown normal brain phenotype and hippocampal morphology and the same level of astrocyte and microglia markers (Brennan et al., 2013). Although in the present study zeta protein was increased only transiently, the possible harmful effect of its increased level should be studied and 14-3-3 protein significance in cancer formation (Hermeking, 2003) should be considered in other studies.

\section{Conclusions}

14-3-3 $\zeta$ could increase BDNF mRNA $6 \mathrm{~h}$ after MCAO in rat. It also could reduce infarct size and neurological severity scores in this model of focal ischemia. In conclusion this study introduces $14-3-3 \zeta$ protein as a potential factor for increasing endogenous BDNF in the brain and also a candidate therapeutic protein against cerebral ischemia.

\section{Conflict of interests}

The authors have no conflict of interests to declare.

\section{Acknowledgements}

This article was extracted from Naeemeh Khalesi's PhD thesis and was supported by the School of Advanced Technologies in Medicine, Shahid Beheshti University of Medical Sciences (Grant Number: 8402), and was carried out at the Cellular and Molecular Biology Research Center, the directors of which we gratefully.

\section{References}

Arai S, Kinouchi H, Akabane A, Owada Y, Kamii H, Kawase M, Yoshimoto $T$ (1996). Induction of brain-derived neurotrophic factor (BDNF) and the receptor trk B mRNA following middle cerebral artery occlusion in rat. Neurosci Lett 211(1): 57-60. DOI: 10.1016/0304-3940(96)12720-8.

Baydyuk M, Xu B (2014). BDNF signaling and survival of striatal neurons. Front Cell Neurosci 8: 254. DOI: 10.1016/j. neures.2010.12.007.

Beck T, Lindholm D, Castren E, Wree A (1994). Brain-derived neurotrophic factor protects against ischemic cell damage in rat hippocampus. J Cereb Blood Flow Metab 14(4): 689-692. DOI: $10.1038 / j c b f m .1994 .86$

Benjamin EJ, Virani SS, Callaway CW, Chamberlain AM, Chang AR, Cheng S, et al. (2018). Heart disease and stroke statistics - 2018 update: a report from the American Heart Association. Circulation 137(12): e67-e492. DOI: 10.1161/CIR.0000000000000558.

Berg D, Holzmann C, Riess O (2003). 14-3-3 proteins in the nervous system. Nat Rev Neurosci 4(9): 752-762. DOI: 10.1038/nrn1197.

Brennan GP, Jimenez-Mateos EM, McKiernan RC, Engel T, Tzivion G, Henshall DC (2013). Transgenic overexpression of 14-3-3 zeta protects hippocampus against endoplasmic reticulum stress and status epilepticus in vivo. PLoS One 8(1): e54491. DOI: 10.1371/journal.pone.0054491.

Brennan GP, Jimenez-Mateos EM, Sanz-Rodriguez A, Mooney CM, Tzivion G, Henshall DC, Engel T (2015). Overexpression of 14-3-3 Increases Brain Levels of C/EBP Homologous Protein CHOP. J Mol Neurosci 56(2): 255-262. DOI: 10.1007/s12031015-0510-0.

Cau Y, Valensin D, Mori M, Draghi S, Botta M (2018). Structure, function, involvement in diseases and targeting of 14-3-3 proteins: An update. Curr Med Chem 25(1): 5-21. DOI: 10.2174/0 929867324666170426095015.

Chalkias A, Xanthos T (2012). Post-cardiac arrest brain injury: pathophysiology and treatment. J Neurol Sci 315(1-2): 1-8. DOI: 10.1016/j.jns.2011.12.007.

Chang CC, Zhang C, Zhang Q, Sahin O, Wang H, Xu J, et al. (2016). Upregulation of lactate dehydrogenase a by 14-3-3 leads to increased glycolysis critical for breast cancer initiation and progression. Oncotarget 7(23): 35270-35283. DOI: 10.18632/oncotarget.9136.

Chen XQ, Fung Y-W, Yu AC (2005). Association of 14-3-3 $\zeta$ and phosphorylated bad attenuates injury in ischemic astrocytes. J Cereb Blood Flow Metab 25(3): 338-347. DOI: 10.1038/ sj.jcbfm.9600032.

Dmitrieva VG, Stavchansky VV, Povarova OV, Skvortsova VI, Limborska SA, Dergunova LV (2016). Effects of ischemia on the expression of neurotrophins and their receptors in rat brain structures outside the lesion site, including on the opposite hemisphere. Mol Biol 50(5): 684-692. DOI: 10.1134/ S0026893316030067.

Fan J, Zhang N, Yin G, Zhang Z, Cheng G, Qian W, et al. (2012). Edaravone protects cortical neurons from apoptosis by inhibiting the translocation of BAX and Increasing the interaction between 14-3-3 and p-BAD. Int J Neurosci 122(11): 665-674. DOI: 10.3109/00207454.2012.707714.

Ferl RJ, Manak MS, Reyes MF (2002). The 14-3-3s. Genome Biol 3: reviews3010. 1. DOI: 10.1186/gb-2002-3-7-reviews3010.

Freed E, Symons M, Macdonald SG, McCormick F, Ruggieri R (1994). Binding of 14-3-3 proteins to the protein kinase Raf and effects on its activation. Science 265(5179): 1713-1716. DOI: 10.1126/ science. 8085158 .

Hankey G (2017). Stroke. Lancet 389(10069): 641-654. DOI: 10.1016/S0140-6736(16)30962-X. 
Hermeking H (2003). The 14-3-3 cancer connection. Nat Rev Cancer 3(12): 931-943. DOI: 10.1038/nrc1230.

Hernandez-Chan NG, Bannon MJ, Orozco-Barrios CE, Escobedo L, Zamudio S, la Cruz F, et al. (2015). Neurotensin-polyplexmediated brain-derived neurotrophic factor gene delivery into nigral dopamine neurons prevents nigrostriatal degeneration in a rat model of early Parkinson's disease. J Biomed Sci 22: 59. DOI: 10.1186/s12929-015-0166-7.

Kasinski A, Dong X, Khuri FR, Boss J, Fu H (2014). Transcriptional regulation of YWHAZ, the gene encoding 14-3-3ל. PLoS One 9(4): e93480. DOI: 10.1371/journal.pone.0093480.

Kawamoto Y, Akiguchi I, Tomimoto H, Shirakashi Y, Honjo Y, Budka H (2006). Upregulated expression of 14-3-3 proteins in astrocytes from human cerebrovascular ischemic lesions. Stroke 37(3): 830-835. DOI: 10.1161/01.STR.0000202587.63936.37.

Kokaia Z, Zhao Q, Kokaia M, Elmer E, Metsis M, Smith ML, et al. (1995). Regulation of brain-derived neurotrophic factor gene expression after transient middle cerebral artery occlusion with and without brain damage. Exp Neurol 136(1): 73-88 DOI: 10.1006/exnr.1995.1085.

Larsson E, Nanobashvili A, Kokaia Z, Lindvall O (1999). Evidence for neuroprotective effects of endogenous brain-derived neurotrophic factor after global forebrain ischemia in rats. J Cereb Blood Flow Metab 19(11): 1220-1228. DOI: 10.1097/00004647-19991100000006.

Levivier M, Przedborski S, Bencsics C, Kang UJ (1995). Intrastriatal implantation of fibroblasts genetically engineered to produce brain-derived neurotrophic factor prevents degeneration of dopaminergic neurons in a rat model of Parkinson's disease. J Neurosci 15(12): 7810-7820. DOI: 10.1523/ JNEUROSCI.15-12-07810.1995.

Li L, Lundkvist A, Andersson D, Wilhelmsson U, Nagai N, Pardo AC, et al. (2008). Protective role of reactive astrocytes in brain ischemia. J Cereb Blood Flow Metab 28(3): 468-481. DOI: $10.1038 /$ sj.jcbfm.9600546.

Lin Y, Zhang J-C, Fu J, Chen F, Wang J, Wu Z-L, Yuan S-Y (2013). Hyperforin attenuates brain damage induced by transient middle cerebral artery occlusion (MCAO) in rats via inhibition of TRPC6 channels degradation. J Cereb Blood Flow Metab 33(2): 253-262. DOI: $10.1038 / \mathrm{jcbfm} .2012 .164$.

Lindvall O, Ernfors P, Bengzon J, Kokaia Z, Smith ML, Siesjo BK, Persson H (1992). Differential regulation of mRNAs for nerve growth factor, brain-derived neurotrophic factor, and neurotrophin 3 in the adult rat brain following cerebral ischemia and hypoglycemic coma. PNAS 89(2): 648-652. DOI: 10.1073/ pnas.89.2.648.

Livak KJ, Schmittgen TD (2001). Analysis of relative gene expression data using real-time quantitative PCR and the 2[-Delta Delta C(T)] method. Methods 25(4): 402-408. DOI: 10.1006/ meth.2001.1262.

Long J, Cai L, Li J, Zhang L, Yang H, Wang T (2013). JNK3 involvement in nerve cell apoptosis and neurofunctional recovery after traumatic brain injury. Neural Regen Res 8(16): 1491-1499. DOI: 10.3969/j.issn.1673-5374.2013.16.006.

Longa EZ, Weinstein PR, Carlson S, Cummins R (1989). Reversible middle cerebral artery occlusion without craniectomy in rats. Stroke 20(1): 84-91. DOI: 10.1161/01.STR.20.1.84.

Lu B, Nagappan G, Guan X, Nathan PJ, Wren P (2013). BDNFbased synaptic repair as a disease-modifying strategy for neurodegenerative diseases. Nat Rev Neurosci 14(6): 401-416. DOI: $10.1038 / \mathrm{nrn} 3505$.

Masters SC, Yang H, Datta SR, Greenberg ME, Fu H (2001). 14-3-3 inhibits Bad-induced cell death through interaction with serine-136. Mol Pharmacol 60(6): 1325-1331. DOI: 10.1124/ mol.60.6.1325.

Mengozzi M, Cervellini I, Villa P, Erbayraktar Z, Gokmen N, Yllmaz O, et al. (2012). Erythropoietin-induced changes in brain gene expression reveal induction of synaptic plasticity genes in experimental stroke. PNAS 109(24): 9617-9622. DOI: 10.1073/ pnas.1200554109.

Müller HD, Hanumanthiah KM, Diederich K, Schwab S, Schäbitz W-R, Sommer C (2008). Brain-derived neurotrophic factor but not forced arm use improves long-term outcome after photothrombotic stroke and transiently upregulates binding densities of excitatory glutamate receptors in the rat brain. Stroke 39(3): 1012-1021. DOI: 10.1161/ STROKEAHA.107.495069.

Murphy N, Bonner HP, Ward MW, Murphy BM, Prehn JH, Henshall DC (2008). Depletion of 14-3-3 zeta elicits endoplasmic reticulum stress and cell death, and increases vulnerability to kainate-induced injury in mouse hippocampal cultures. J Neurochem 106(2): 978-988. DOI: 10.1111/j.14714159.2008.05447.x.

Nagahara AH, Tuszynski MH (2011). Potential therapeutic uses of BDNF in neurological and psychiatric disorders. Nat Rev Drug Discov 10(3): 209-219. DOI: 10.1038/nrd3366.

Nagahara AH, Merrill DA, Coppola G, Tsukada S, Schroeder BE, Shaked GM, et al. (2009). Neuroprotective effects of brain-derived neurotrophic factor in rodent and primate models of Alzheimer's disease. Nat Med 15(3): 331-337. DOI: 10.1038/nm.1912.

Neasta J, Kiely PA, He D-Y, Adams DR, O'Connor R, Ron D (2011). Direct interaction between the scaffolding proteins RACK1 and 14-3-3 $\zeta$ regulates brain-derived neurotrophic factor (BDNF) transcription. J Biol Chem 287(1): 322-336. DOI: 10.1074/jbc. M111.272195.

Neumann JT, Thompson JW, Raval AP, Cohan CH, Koronowski KB, Perez-Pinzon MA (2015). Increased BDNF protein expression after ischemic or PKC epsilon preconditioning promotes electrophysiologic changes that lead to neuroprotection. J Cereb Blood Flow Metab 35(1): 121-130. DOI: 10.1038/jcbfm.2014.185

Neumar RW (2000). Molecular mechanisms of ischemic neuronal injury. Ann Emerg Med 36(5): 483-506. DOI: 10.1067/ mem.2000.110995.

Noh HS, Kim YS, Kim YH, Han JY, Park CH, Kang AK, et al. (2006). Ketogenic diet protects the hippocampus from kainic acid toxicity by inhibiting the dissociation of bad from 14-3-3. J. Neurosci Res 84(8): 1829-1836. DOI: 10.1002/jnr.21057.

Nolan JP, Neumar RW, Berg RA, Böttiger BW, Clark RS, Geocadin RG et al. (2008). Post-cardiac arrest syndrome. Resuscitation 79(3): 350-379. DOI: 10.1016/j.resuscitation.2008.09.017.

Numakawa T, Suzuki S, Kumamaru E, Adachi N, Richards M, Kunugi H (2010). BDNF function and intracellular signaling in neurons. Histol Histopathol 25(2): 237-258. DOI: 10.14670/HH25.237.

Okuno H (2011). Regulation and function of immediate-early genes in the brain: beyond neuronal activity markers. Neurosci Res 69(3): 175-186. DOI: 10.1016/j.neures.2010.12.007.

Pekny M, Pekna M (2014). Astrocyte reactivity and reactive astrogliosis: costs and benefits. Physiol Rev 94(4): 1077-1098. DOI: 10.1152/physrev.00041.2013.

Pirim I (1998). Ischemic rat brains contain immunoreactivity of 14-3-3 proteins. Int J Neurosci 95(1-2): 101-106. DOI: 10.3109/00207459809000653.

Rennke HG, Patel Y, Venkatachalam MA (1978). Glomerular filtration of proteins: clearance of anionic, neutral, and cationic horseradish peroxidase in the rat. Kidney Int 13(4): 278-288. DOI: 10.1038/ki.1978.41.

Rickhag M, Teilum M, Wieloch T (2007). Rapid and long-term induction of effector immediate early genes (BDNF, Neuritin and $\mathrm{Arc}$ ) in peri-infarct cortex and dentate gyrus after ischemic injury in rat brain. Brain Res 1151: 203-210. DOI: 10.1016/j. brainres.2007.03.005.

Sacco RL, Kasner SE, Broderick JP, Caplan LR, Connors JJ, Culebras A, et al. (2013). An updated definition of stroke for the 21st century: a statement for healthcare professionals from the American Heart Association/American Stroke Association. Stroke 44(7): 2064-2089. DOI: 10.1161/STR.0b013e318296aeca.

Schäbitz W-R, Schwab S, Spranger M, Hacke W (1997). Intraventricular brain-derived neurotrophic factor reduces infarct size after focal cerebral ischemia in rats. J Cereb Blood Flow Metab 17(5): 500-506. DOI: 10.1097/00004647-199705000-00003.

Schäbitz W-R, Sommer C, Zoder W, Kiessling M, Schwaninger M, Schwab S (2000). Intravenous brain-derived neurotrophic factor reduces infarct size and counterregulates Bax and Bcl-2 expression after temporary focal cerebral ischemia. Stroke 31(9): 2212-2217. DOI: 10.1161/str.31.9.2212.

Schäbitz W-R, Steigleder T, Cooper-Kuhn CM, Schwab S, Sommer C, Schneider A, Kuhn HG (2007). Intravenous brain- 
derived neurotrophic factor enhances poststroke sensorimotor recovery and stimulates neurogenesis. Stroke 38(7): 2165-2172. DOI: 10.1161/STROKEAHA.106.477331.

Schmidt-Kastner R, Truettner J, Lin B, Zhao W, Saul I, Busto R, Ginsberg MD (2001). Transient changes of brain-derived neurotrophic factor (BDNF) mRNA expression in hippocampus during moderate ischemia induced by chronic bilateral common carotid artery occlusions in the rat. Mol Brain Res 92(1-2): 157-166. DOI: 10.1016/S0169-328X(01)00157-7.

Shruthi S, Sumitha R, Varghese AM, Ashok S, Chandrasekhar Sagar BK, et al. (2017). Brain-derived neurotrophic factor facilitates functional recovery from als-cerebral spinal fluid-induced neurodegenerative changes in the NSC-34 motor neuron cell line. Neurodegener Dis 17(1): 44-58. DOI: $10.1159 / 000447559$.

Silva A, Naia L, Dominguez A, Ribeiro M, Rodrigues J, Vieira OV, et al. (2015). Overexpression of BDNF and full-length TrkB receptor ameliorate striatal neural survival in huntington's disease. Neurodegener Dis 15(4): 207-218. DOI: 10.1159/000375447.

Siman R, Zhang C, Roberts VL, Pitts-Kiefer A, Neumar RW (2005). Novel surrogate markers for acute brain damage: cerebrospinal fluid levels corrrelate with severity of ischemic neurodegeneration in the rat. J Cereb Blood Flow Metab 25(11): 1433-1444. DOI: $10.1038 /$ sj.jcbfm.9600138.

Smani D, Sarkar S, Raymick J, Kanungo J, Paule MG, Gu Q (2018). Downregulation of 14-3-3 proteins in a kainic acid- induced neurotoxicity model. Mol Neurobiol 55(1): 122-129. DOI: 10.1007/s12035-017-0724-y.

The BDNF Study Group (1999). A controlled trial of recombinant methionyl human BDNF in ALS. Neurology 52(7): 1427. DOI: 10.1212/WNL.52.7.1427.

Umahara T, Uchihara T, Tsuchiya K, Nakamura A, Iwamoto T (2007). Intranuclear localization and isoform-dependent translocation of 14-3-3 proteins in human brain with infarction. J Neurol Sci 260(1-2): 159-166. DOI: 10.1016/j.jns.2007.04.053.

Wang C, Liu M, Pan Y, Bai B, Chen J (2017). Global gene expression profile of cerebral ischemia-reperfusion injury in rat MCAO model. Oncotarget 8(43): 74607-74622. DOI: 10.18632/ oncotarget.20253.

Yuan JS, Reed A, Chen F, Stewart CN (2006). Statistical analysis of real-time PCR data. BMC Bioinformatics 7(1): 85 . DOI: 10.1186/1471-2105-7-85.

Zheng F, Zhou X, Moon C, Wang H (2012). Regulation of brainderived neurotrophic factor expression in neurons. Int J Physiol Pathophysiol Pharmacol 4(4): 188-200.

Zhu Y, Bu Q, Liu X, Hu W, Wang Y (2014). Neuroprotective effect of TAT-14-3-3 fusion protein against cerebral ischemia/reperfusion injury in rats. PLoS One 9(3): e93334. DOI: 10.1371/journal. pone.0093334.

Zuccato C, Cattaneo E (2009). Brain-derived neurotrophic factor in neurodegenerative diseases. Nat Rev Neurol 5(6): 311-322. DOI: 10.1038/nrneurol.2009.54. 